DOI 10.30740/jee.v1i1p41-50.5

\title{
THE STRATEGY OF MANAGERS IN MOVING BUSINESS LEARNING GROUP PROGRAM IN PKBM SRIKANDI CIMAHI CITY
}

\author{
Dinno Mulyono \\ IKIP Siliwangi, Jl. Terusan Jenderal Sudirman, Cimahi, West Java, Indonesia \\ bertiup@yahoo.com
}

Received: Desember 15, 2017; Accepted: January 5, 2018

\begin{abstract}
This research is one way in describing the strategy of managers in moving the business group learning program for street children developed in PKBM Srikandi Kota Cimahi. Business group learning program is one of the containers in building independence for youth and street children who are expected to build entrepreneurial character. The purpose of this study is to describe the strategies undertaken by managers in moving the group learning business program. The theory underlying this research is the Concept of Management Unit Outside School Education, Concept Group Business Learning, Street Children Concept. The method of this research is qualitative descriptive with data collection technique using interview, observation and documentation study. The results obtained show that the group manager of PKBM Srikandi uses a persuasive approach in fostering self-confidence in the learning community, using motivation to encourage self-reliance in creative and solu- tive thinking, and using a test case approach to build resilience in developing a business. This research resulted in the conclusion that humanist, communicative and motivative management strategy able to build and develop self-reliance learners to develop their business independently.
\end{abstract}

Keywords: Business Learning Group, Manager

\begin{abstract}
Abstrak
Penelitian ini merupakan salah satu cara dalam mendeskripsikan strategi pengelola dalam menggerakkan program kelompok belajar usaha bagi anak jalanan yang dikembangkan di PKBM Srikandi Kota Cimahi. Program kelompok belajar usaha merupakan salah satu wadah dalam membangun kemandirian bagi pemuda dan anak jalanan yang diharapkan dapat membangun karakter kewirausahaan. Tujuan penelitian ini adalah mendeskripsikan strategi yang dilakukan oleh pengelola dalam menggerakkan program kelompok belajar usaha. Teori yang melandasi penelitian ini adalah Konsep Manajemen Satuan Pendidikan Luar Sekolah, Konsep Kelompok Belajar Usaha, Konsep Anak Jalanan. Adapun metode penelitian ini adalah deskriptif kualitatif dengan teknik pengumpulan data menggunakan wawancara, observasi dan studi dokumentasi. Hasil yang diperoleh menunjukkan bahwa pengelola Kelompok Belajar Usaha PKBM Srikandi menggunakan strategi pendekatan persuasif dalam menumbuhkan kepercayaan diri warga belajar, menggunakan motivasi untuk mendorong kemandirian dalam berfikir kreatif dan solutif, serta menggunakan pendekatan uji kasus untuk membangun ketahanan dalam mengembangkan usaha. Penelitian ini menghasilkan kesimpulan bahwa strategi pengelola yang humanis, komunikatif dan motivatif mampu membangun dan mengembangkan kemandirian warga belajar untuk mengembangkan usaha secara mandiri.
\end{abstract}

Kata Kunci: Kelompok Belajar Usaha, Pengelola

How to Cite: Mulyono, D. (2018). The Strategy of Managers in Moving Business Learning Group Programin PKBM Srikandi Cimahi City. JEE, 1 (1), 37 - 44. 


\section{INTRODUCTION}

Rapid population growth, encouraging sociological conditions that can lead to tremendous growth, such as the expansion of the marketing network of economic commodities, with the addition of a large market share, will accelerate also the flow of economic flows in society that will encourage the development economic condition of society. In addition, proper population growth will also be the subject of productive development, however this needs to be balanced with the development of sufficient resources. The greatest concerns of the demographic conditions in population development partially follow the opinion of Thomas Malthus (1766-1834) which states that population growth tends to follow the geometrical progression, while the food supply tends to grow in arithmetic. So that when a human needfulfilling device is limited in its availability, then unable to meet human needs itself, it will push the human into the swamp of poverty and hunger.

Cimahi City which has an area of only $40.25 \mathrm{~km} 2$ in 2017 has increased by 1,000 residents, it is recognized by the Head of Population and Civil Registry (Disdukcapil) Cimahi, M. Suryadi. He said that in 2016 the population of Cimahi amounted to 521.909, while in 2015 only amounted to about 520 thousand inhabitants (Cakrawalamedia.co.id). With the condition of the area and the population, the City Cimahi has a density that exceeds the ideal limit for population density in the City. This has led to a number of problems, including unemployment and demand for commodities that become the needs of the people.

Physical development can not be a reference in improving the quality of human life today. According Syamsi Y.Z. Basri and M. Subri (2006: 15) development is a process of systemic change that is directed towards improvements oriented in the modernization of development and economic social progress. Therefore, according to E. Rochaida (2016: 15) states that the new paradigm of development has shifted to the importance of human dimension development (people centered development). Many experts say that the population is not only an objective of development but also as the subject of development. Because, it is required that the population must participate as a subject, it is necessary to improve the quality of human resources so that the desired development can be achieved.

Community Learning Activity Center (PKBM) Srikandi Kota Cimahi has implemented several programs related to improving the economic capacity of the community, especially in business group learning programs. Efforts to develop business learning groups are one way to improve the capacity of the community, especially the youth and street children to develop and build self-reliance in order to be equal with other community groups in the community. Residents of learning that almost all of them have backgrounds from street children to be unique in achieving the target of this business group itself in the midst of the challenges and problems that exist in building better people's lives. Given these conditions, it is necessary to investigate about, "What is the strategy of managers in moving the group learning business program PKBM Srikandi City Cimahi?".

\section{THEORETICAL BASIS}

\section{Concept of Management Unit of School Outside Education}

According to D. Sudjana (2004: 1), three important terms in the definition of Outside School Management Program Management is Management, Program and Out of School Education. Management itself means all activities organized by someone or more, in a group or organization / institution to achieve the goals set by the organization / institution. Programs can be defined as activities undertaken by individuals or groups that contain program 
components. The components include objectives, objectives, content and type of activities, process of time activities, facilities, costs and organization of the organization. Off-school education is that learning occurs organized outside the formal schooling system or formal education, whether implemented separately or as an essential part of a larger activity intended to serve a particular educational objective and particular learning. Management becomes a very important factor in the activities of the institution to achieve the desired goal in order to achieve an efficient and satisfactory results. So, this management is very important because in addition to the nature of knowledge is also the expertise of managers or leaders in solving organizational problems through a system mechanism that can be used. Management in an off-school education unit focuses on explaining planning, organizing, actualizing and monitoring. The purpose of management itself, according to Brantas (2009: 13-14) is, first, the guidelines for activities, secondly, the standard of implementation and the rational basis of organizing. By using appropriate management, it can support the development of a more measurable and productive school unit program.

\section{Concept of Business Learning Group}

Business Learning Group is a program intended to improve the welfare of the community through the business / business community either done in groups or together. The real purpose of a business learning group is to cultivate an entrepreneurial spirit for a skilled society but has a passion for changing its fate by exploiting opportunities that are maximally facilitated by the government. With the development of Business Learning Group (KBU) PKBM is expected to appear small entrepreneurs who can support the economy at the local and even national level. The role of KBU in community empowerment according to Gito Yuliantoro (2008: 55-56) becomes very important and strategic with the consideration that the success of the program will be expected to improve the capacity of the poor through business skills that encourage economic improvement and indirectly also affects the decrease in the number of children dropping out of school for economic reasons, as well as reduced number of school dropouts for economic reasons and increased employment for unemployed people, in this case are street children who are members of KBU PKBM Srikandi Kota Cimahi.

\section{Street Children's Concept}

According to the Ministry of Social Affairs (2005: 5), street children are children who spend most of their time doing daily living activities on the streets, either to earn a living or to roam the streets and other public places. In the business group learning program PKBM Srikandi, street children become one of the important notes in building community welfare and independence in entrepreneurship. Nevertheless, in this study will be more about the street children's self concept in building entrepreneurial character related to the independence of street children in the midst of life challenge of Cimahi City which is getting more crowded and has implication to the development of prosperity and capacity of economy of society itself. According to Muslim and Mardiyati (2004) in Y. Pramuchtia and N.K. Pandjaitan (2010: 256) mentions that the self-concept of street children need to be understood because the child's self concept has a great influence on the overall behavior of someone displayed. By understanding the differences of street children's self-concept based on their characteristics, then the guidance of street children will be right in accordance with the street children's selfconcept.

\section{RESEARCH METHODS}

The research method used is qualitative research, with the aim to improve the deepening of existing cases in accordance with real field conditions. While the technique of data collection 
is an interview conducted on 1 person manager with respondents named YY, 3 people studying citizens (AC, OO, DN) and 2 community leaders (DD and OC). The respondents in this study reflect triangulation, in which the data source is selected from three different parties. Besides that, there are also observations on the learning group program that is implemented as a way to follow the process of the implementation of the business learning group program in PKBM Srikandi and as supporting data is also used to study the documentation of the data available in PKBM Srikandi as supporting data.

\section{DISCUSSION}

The role of the manager is the expected behavior of a person's status as a manager, a person who runs, moves or organizes an organization, group or association. With the manager, coordination, work corridor and activity mechanism can run well. In this study, the role of managers is the behavior displayed by managers in performing tasks related to improving the quality of community life through business learning groups (KBU) PKBM Srikandi, Kota Cimahi.

Managers in this case are Chairman of PKBM and Chairman of Group Business Learning, is an element of managers in the implementation of Business Learning Group programs implemented in PKBM Srikandi. Therefore, it is necessary to study the impact of managers in the development of business group learning programs implemented in PKBM Srikandi. Thus, it can be used as a comparison in developing and building characters available to other business learning groups, in other PKBM. In the hope of providing enlightenment and comparison for community development through non formal education, especially in business group learning programs (KBU). Because the role of managers is considered very important in determining the success of programs implemented at the Community Learning Center (D.F. Sutisna, et.al, 2012, 1-17).

Based on the results of the study shows that the residents learn business group learning as well as OO, DN and AC indicate that there is a learning process that they do to develop their skills. Such as from the initial encouragement and interest to follow the business group learning program, to determine / choose the type of business to be done to increase revenue. In reality, there has been a lot of things that make the added value itself not only a mere increase in income, but other improvements such as social status, knowledge of product marketing strategies, even the ability to identify market needs, and self-understanding and the environment. The result has been confronted with the opinion expressed by $\mathrm{D}$ and $\mathrm{O}$ who are the representatives of the community surrounding the group of business learning group PKBM Srikandi, Cimahi city. This is in accordance with the opinion of Kamil (2011: 99) which suggests that Group learning business is an activity to membelajarkan citizens to catch up in the field of business by working, learning and trying to obtain livelihood as a source of decent income. Business learning group (KBU) as one of the community education programs that provide skills and businesses in which there are learning and business activities. By using various approaches, the managers have succeeded in establishing mutually reinforcing togetherness with the learning community, so that the business group learning program can be run in accordance with the needs of the learning community, this is in accordance with the pattern of partnership development implemented by the PKBM manager is through the construction of existing trust among the components of the Community Learning Center, especially building trust (M. Arief Rizka, 2016: 17). Partnerships that are formed not only based on the income of funds alone, but efforts to strengthen the quality of the program better. 
By consistently doing the same thing more consistently, and driven by a good managerial strategy, the products produced by the business learning group have increased significantly. Among them is to form and build a network of partnerships and understand about the potential of self and the environment. This becomes an important part of building the capacity of self and society, in order to improve the quality of life. In accordance with the opinion of Anissa L. Kadiyono (2014, 25-38) who expressed that entrepreneurship can also be encouraged by someone who runs entrepreneurship, because it has given inspiration and interest to entrepreneurship.

With these abilities then the learning community will strive to continue to develop themselves and improve the quality of life, the residents of learning now continue to strive to try and improve the quality of life, especially the capacity of the economy. This indicates that the strategy undertaken by the managers is able to encourage the learners to develop more productively, in accordance with the opinion of Wijayanti and B. Ismanto (2015) related to the development of the ability to understand the potential of self and the environment that can affect the quality of business group learning programs at the Learning Activity Center Community (PKBM). The learning process through this business learning group is in accordance with the study in the national journal on "Small Business Group-Based Business Unit Development Model" (Oong Komar: 2014), "Student-centered learning groups based on curriculum and learning process will significantly develop learning habits, work, start a member ".

In particular, this is in accordance with the theory of community development through nonformal education as disclosed by Paulo Freire (1984: 76) which reveals that the most important thing in changing the living conditions of society is the formation of awareness of himself and the surrounding environment. With the ability to identify the condition of self and his environment, he has built a critical awareness, where he is able to identify problems as well as provide solutions to what is the problem in his life. According to M. Umar (2015: 24) revealed that the interest of learning owned by children, impact on the seriousness of children's learning can impact on children's learning achievement. Therefore, the interest of children's learning is necessary to always be stimulated, so that the learning achievement of children can be achieved optimally. Thus, it can be explained that the learning process undertaken within the business learning group PKBM Srikandi encourages the growth of motivation to learn in accordance with the needs and interests of the learning community Business Learning Group (KBU) PKBM Srikandi Kota Cimahi. This is in line with Herlina's opinion (2016: 60-64) which suggests the effectiveness of empowerment programs can be much more effective when appropriate with the motivation and needs of the learning community. So they can develop with a firm responsibility for personal development and the environment.

While the interest that became the main driving factor of the people learning to follow the business group learning program is one of the efforts and the initial role of managers in improving the quality of community life around PKBM Srikandi. The ability to attract people is included in the human skill of skills to work together, motivate and direct. The same is stated by Yukl (1994) which states human relationships are skills or the ability to understand the feelings of others, the ability to communicate clearly and effectively, and the ability to make effective and cooperative relationships. Thus, in the case of business group learning PKBM Srikandi the manager has shown that in the process of implementation of existing programs, can be done by implementing a more humane approach and make each person able to develop each other. Thus encouraging the ability to work together mutually benefit each 
other. According to Marlinda Sari (2016: 8) states that the role of non-formal education in the national education system goes hand in hand with the role of formal education, so that the implementation of the equality program must have broadened the range of target and quality improvement. Therefore, with a better approach in the Business Learning Group program, it is expected to provide a new perception in the strengthening of non-formal education programs. Especially by providing motivation, mentoring and support in non-formal education programs conducted at the Community Learning Activity Center (Marlinda Sari, 2016: 12).

Meanwhile, in the management of Business Learning Group PKBM Srikandi, put forward approaches related to efforts to synergize some components of school education together and sustainable. So as to develop various approaches in a sustainable manner and as a system, as disclosed by D. Sudjana (2001: 67) which states that PLS can be viewed as a system. Which means that PLS has interrelated components in order to achieve a goal. This can be seen from the various approaches that exist to build each other in order to develop a comprehensive approach system in the business group learning program PKBM Srikandi. For example is the existence of residents learn as raw input, conditioning partnerships and curriculum as instrumental input, conditioning space and place of learning as an enviromental input that became one of the main support to build the character of citizens learn better. Especially with the existence of various learning tools related to the effort of learning to learn from existing approaches, especially those related to training of aloe vera pudding, cookies and sewing training. The various forms of cooperation among the various components of off-the-shelf education in PKBM Srikandi become one of the supporters in strengthening the learning process implemented in the business learning group (KBU), especially in the strengthening of learning materials and experiences, as revealed by Ajisukmo (2012: 13) which states that the importance of cooperation among learning components of street children is in sharing experiences and learning materials that can be used for children's education.

\section{CONCLUSION}

Based on the findings in the field, it is found that the strategy of managing the group of business learning in moving the business learning group is by as much as possible to attract the learners, either by informal communication strategy or by social approach. In addition, another strategy is to encourage the learners to be actively involved in choosing the type of business, so that the learners have a clear reason to be able to develop the type of business they choose. Managers also carry out coaching, either with a communicative approach or by using a practical approach in the activity of business learning groups. As one of the continuation of the program, the manager also directs the learning community to know the techniques and strategies in marketing the product. Supported by efforts to encourage increased cooperation among the study group learning community. In addition, the manager is able to demonstrate his strategy in facilitating, motivating and becoming a catalyst (providing direction and guidance so as to accelerate the learning process) for the learning community. So it can help residents learn in identifying internal and external support factors that can be used in developing their business.

\section{REFERENCES}

Ajisukmo, Clara.R.P. 2012. Faktor-faktor Penting dalam Merancang Program Pendidikan Luar sekolah untuk Anak Jalanan dan Pekerja Anak. Jurnal Makara, Sosial Humaniora, Volume 16 No.1 Juli 2012. 
Basri, Y.Z. dan Mulyadi Subri. 2006. Keuangan Negara dan Analisis Kebijakan Utang Luar Negeri. Jakarta; Raja Grafindo

Brantas, Drs. 2009. Dasar-dasar Manajemen. Bandung : Alfabeta.

Freire, P. 1984. Pendidikan Kaum Tertindas. Yogyakarta; LP3ES.

Herlina. 2016. Keefektifan Program Pemberdayaan Perempuan Melalui Pemberian Modal Usaha Kursus Menjahit. Jurnal Paedagogy Vol 3 No. 1, Mei 2016, FKIP Mataram. [Online]. Tersedia $\quad: \quad$ http://fip.ikipmataram.ac.id/wpcontent/uploads/2015/03/HERLINA_KEEFEKTIFAN-PROGRAMPEMBERDAYAAN-PEREMPUAN-MELALUI-PEMBERIAN-MODAL-USAHAKURSUS-MENJAHIT1.pdf. Diakses : 12 Februari 2017.

Kadiyono, A.L. 2014. Efektivitas Pengembangan Potensi Diri dan Orientasi Wirausaha dalam Meningkatkan Sikap Wirausaha. Jurnal Intervensi Psikologi Volume 6 No.1 Juni 2014. Hal 25-32. [Online]. Tersedia http://download.portalgaruda.org/article.php?article=422561\&val=8162\&title=EFEKT IVITAS\%20PENGEMBANGAN\%20POTENSI\%20DIRI\%20DAN\%20ORIENTASI $\%$ 20WIRAUSAHA\%20DALAM\%20MENINGKATKAN\%20SIKAP\%20WIRAUSA HA. Diakses : 12 Juni 2017

Kamil, M. (2006). Pendidikan Nonformal, Pengembangan Melalui PKBM. Bandung; Alfabeta.

Komar, Oong. 2004. Model Pengembangan Kelompok Belajar Usaha Berbasis Unit Usaha Kecil. Jurnal Sosiohumaniora, Volume 4 No.2 Juli 2004

Pramuchtia, Y dan N.K. Pandjaitan. 2010. Konsep Diri Anak Jalanan: Kasus Anak Jalanan di Kota Bogor Provinsi Jawa Barat. Jurnal Soladity: Jurnal Transdisiplin Sosiologi, Komunikasi dan Ekologi Manusia. Volume 4 No. 5, Agustus 2010.

Rizka, M. Arief. 2016. Analisis Strategi Kemitraan Dalam Penyelenggaraan Program Pendidikan Nonformal (Studi Kasus Pada PKBM Terampil). Jurnal Paedagogy, Fakultas Ilmu Pendidikan IKIP Mataram. Volume 3 No. 1 Mei 2016, Hal. 12-19.

Rochaida, E. 2016. Dampak Pertumbuhan Penduduk Terhadap Pertumbuhan Ekonomi dan Keluarga Sejahtera di Provinsi Kalimantan Timur. Jurnal Forum Ekonomi, Volume 18 No. 1 tahun 2016

Sari, Marlinda. 2016. Implementasi Pembelajaran Pendidikan Kesetaraan di Pusat Kegiatan Belajar Masyarakat (PKBM) Tamanan Kecamatan Banguntapan, Kabupaten Bantul. Jurnal Pendidikan dan Ekonomi Volume 5 No. 1 tahun 2016. Hal. 6-13

Sudjana, D. 2001. Pendidikan Luar Sekolah, Wawasan sejarah Perkembangan Falsafah dan Teori \& Pendukung Azas. Bandung: Falah Production.

Sudjana, D. 2004. Manajemen Program Pendidikan untuk Pendidikan Non Formal dan Pengembangan Sumber Daya Manusia. Bandung : Falah Production.

Sutisna, D.F, Sinaga, D dan Rosfiantika, E. 2012. Peranan PKBM dalam Menumbuhkan Minat Baca Warga Belajar. [Online]. eJurnal Mahasiswa Universitas Padjadjaran, Volume 1 N0. 1, 2012, hal. 1-17. Tersedia http://download.portalgaruda.org/article.php?article=103525\&val=1378

Umar, M. 2015. Peranan Orang Tua dalam Meningkatkan Prestasi Belajar Anak. Jurnal Ilmiah Edukasi Volume 1 No.1 Juni 2015, Hal. 20-28.I 
44 Mulyono, D. (2018). The Strategy of Managers in Moving Business Learning Group Programin PKBM Srikandi Cimahi City. JEE, 1 (1), 37 - 44.

Wijayanti dan B. Ismanto. 2015. Strategi Pengelolaan Pusat Kegiatan Belajar Masyarakat dalam Menyelenggarakan Program Keaksaraan Berbasis Seni Budaya Lokal. Jurnal Widya Vol 17 No. 1, Januari 2015. [online]. Tersedia : ris.uksw.edu/download/jurnal/kode/J01044.

Yuliantoro, G. 2008. Pemberdayaan Masyarakat Melalui Kelompok Belajar Usaha di Pusat Kegiatan Belajar Masyarakat (PKBM). Tugas Akhir Magister Profesional, Program Studi Magister Profesional Pengembangan Masyarakat, Institut Pertanian Bogor. Tidak diterbitkan.

Yukl, G.A. (2004). Leadership in Organization. New York; Parentice Hall

Cakrawala Media. 2017. Jumlah Penduduk Kota Cimahi Mengalami Peningkatan. Sumber : https://www.cakrawalamedia.co.id/jumlah-penduduk-kota-cimahi-mengalamipeningkatan/. Diakses : 18 Agustus 2017 